\title{
Hydrochemical characterization of shallow groundwater from the Mesta River basin
}

\author{
Tanya Vasileva ${ }^{1}$, Aglaida Toteva ${ }^{1}$ \\ ${ }^{1}$ Geological Institute, Bulgarian Academy of Sciences, 1113 Sofia, Bulgaria; \\ e-mail: tanyav@geology.bas.bg; aglaya.j@abv.bg
}

\section{Хидрохимична характеристика на подземните води с активен водообмен от басейна на р. Места}

\section{Таня Василева, Аглаида Тотева}

Vasileva, T., A. Toteva. 2019. Hydrochemical characterization of shallow groundwater from the Mesta River basin. Engineering Geology and Hydrogeology, 33, 15-26.

\begin{abstract}
Groundwater is a valuable natural resource and an important source of drinking and domestic water supply. There are two types of groundwater in the Mesta River Basin: $\mathrm{HCO}_{3}^{-}>$ $\mathrm{Ca}^{2+}+\mathrm{Mg}^{2+}\left(1^{\text {st }}\right.$ type waters) and $\mathrm{HCO}_{3}{ }^{-}<\mathrm{Ca}^{2+}+\mathrm{Mg}^{2+}<\mathrm{HCO}_{3}{ }^{-}+\mathrm{SO}_{4}{ }^{2-}\left(2^{\text {nd }}\right.$ type waters $)$. The waters of the first type formed in the silicate rocks, are widespread in the high mountain, mountain and low mountain area. These waters are attached to the region of regional fracturing of the Precambrian metamorphic complex represented by gneisses, granitogneisses, amphibolites and to the fractured environment of the southern Bulgarian granites and granitoids, quartzites, conglomerates and marls of the Paleozoic. The waters of the second type are characteristic of the valleys covered by Pliocene and Quaternary sediments with minimal precipitation. Groundwater from the Mesta River catchment area is mainly hydrocarbonate-calcium-magnesium with high sodium content in the southern part of the catchment area. The content of anions in groundwater is in the sequence: $\mathrm{HCO}_{3}{ }^{-}>\mathrm{SO}_{4}{ }^{2-}$ $>\mathrm{Cl}^{-}$. The cations are arranged in the order: $\mathrm{Ca}^{2+}+\mathrm{Mg}^{2+}>\left(\mathrm{Na}^{+}+\mathrm{K}^{+}\right)$or $\mathrm{Ca}^{2+}>\left(\mathrm{Na}^{+}+\mathrm{K}^{+}\right)>\mathrm{Mg}^{2+}$. Groundwater is very soft to moderately hard, fresh, with TDS content up to $0.5 \mathrm{~g} / 1$ and chloride content below $10 \mathrm{mg} / \mathrm{l}$.
\end{abstract}

Keywords: groundwater, chemical composition, catchment area, Mesta River.

Резюме. Подземните води са ценен природен ресурс и важен източник за питейно-битово водоснабдяване. В басейна на р. Места се отделят два типа подземни води: $\mathrm{HCO}_{3}{ }^{-}>\mathrm{Ca}^{2+}+\mathrm{Mg}^{2+}$ (води от първи тип) и $\mathrm{HCO}_{3}{ }^{-}<\mathrm{Ca}^{2+}+\mathrm{Mg}^{2+}<\mathrm{HCO}_{3}{ }^{-}+\mathrm{SO}_{4}{ }^{2-}$ (води от втори тип). Най-широко разпространение имат водите от пьрвия тип, формирани в силикатните скали, разпространени във високопланинската, планинската и нископланинската зона. Тези води са привързани към зоната на регионалната напуканост на докамбрийския метаморфен комплекс, представен от гнайси, гранитогнайси, амфиболити и към пукнатинната среда на южнобългарските гранити и гранитоиди, кварцитите, конгломератите и мергелите на палеозоя. Водите от втория тип са характерни за котловините, покрити от плиоценски и кватернерни седименти с минимални валежи. Подземните води от водосборния басейн на р. Места са хидрокарбонатно-калциевомагнезиеви с повишено съдържание на натрий в южната част на водосбора. Съдържанието 
на анионите в подземните води е в последователността: $\mathrm{HCO}_{3}{ }^{-}>\mathrm{SO}_{4}{ }^{2-}>\mathrm{Cl}^{-}$. Катионите са подредени в реда: $\mathrm{Ca}^{2+}>\mathrm{Mg}^{2+}>\left(\mathrm{Na}^{+}+\mathrm{K}^{+}\right)$или $\mathrm{Ca}^{2+}>\left(\mathrm{Na}^{+}+\mathrm{K}^{+}\right)>\mathrm{Mg}^{2+}$. Подземните води са от много меки до умерено твърди, пресни, с минерализация до $0,5 \mathrm{~g} / 1$ и съдържание на хлор под $10 \mathrm{mg} / 1$.

Ключови думи: подземни води, химичен състав, водосборен басейн, р. Места.

\section{Въведение}

Произходът на подземните води определя техните физико-химични свойства и състав. Факторите за формиране състава на подземните води са многообразни. Тяхната интензивност е свързана с конкретна природна среда. Пьрвостепенно значение за състава на подземните води, динамиката и режима им имат физикогеографските (релеф, климат, хидроложки условия) и геоложките фактори (геоложки строеж, литоложки състав на скалите). В настоящата статия е анализиран естественият химически състав на подземните води от водосборния басейн на р. Места. След анализ на информацията от мониторинга за качество на подземните води за района (ПУРБ, 2016-2021) ${ }^{1}$ естественото състояние на водите се охаректеризира по обобщените данни от Т. Кехайов $(1982 \phi)^{2}$ по отделни химични компоненти. Изходният материал включва резултати от химични анализи на подземните води от различни пунктове (извори, кладенци, дренажи), разположени на територията на цялата страна, на база на които са изчертани растерни карти с пространственото разпределение на отделни химични показатели.

\section{Обща характеристика на района на изследване}

За характеризиране на химичния състав на подземните води е избран водосборът на р. Места, който съгласно площта си се отнася към големите водосбори (Директива 2000/60/EO) ${ }^{3}$.

Поречието на р. Места се намира в Ю3 България (фиг. 1) и заема площ от около $2785 \mathrm{~km}^{2}$. Включва долините на р. Места и нейните притоци и част от масивите на оградните планини Пирин, Рила и Западни Родопи. В района изцяло попадат морфоложките единици Разложка и Гоцеделчевска котловина. От хидрогеоложкото райониране на България, поречието попада в Рило-Пиринския район и част от Централно-Родопския район на Рило-Родопската област (Antonov, Danchev, 1980). По данни от геоложката карта на България в М 1:500 000 (Cheshitev, Kanchev, eds, 1989) в изследвания басейн най-голямо разпространение имат скалите на Докамбрия (мрамори, доломити, гнайси, шисти) и Палеозоя (южнобългарски гранити и гранодиорити). Релефът на водосбора е основно ниско (30 \%) и среднопланински (44\%) с денудационни заравнености, на места интензивно разчленен. Хълмисто-котловинният релеф е около $8 \%$ от басейна на р. Места. Отделните котловини имат различна надморска височина с големи различния: около 700-850 m за Разложката, а за Гоцеделчевската 500-600 m. Средната надморска височина за целия водосбор е около $1635 \mathrm{~m}$. Водосборният басейн принадлежи към континентално-средиземноморската област и само найюжните склонове и била на Рила към преходно-континенталната област (Sabev,

${ }^{1}$ ПУРБ (2016-2021), План за управление на речните басейни в Западнобеломорски район (2016-2021 г.), Раздел 4. Мониторинг и оценка на състоянието на повърхностните води, подземните води и зоните за защита на водите. Приложения към Раздел 4.

${ }^{2}$ Кехайов, Т. 1982. Атлас Хидрохимични карти на подземните води от хипергенната зона в НР България, М 1:1 000 000, Комитет по Геология, Научноизследователски институт по полезни изкопаеми.

${ }^{3}$ Директива 2000/60/ЕО на Европейския парламент и на Съвета за установяване на рамка за действията на Общността в областта на политиката за водите. 
Stanev, 1969). Средната годишна сума на валежите варира от около 650 до около 800-900 mm (Koleva, Peneva, 1990). Средногодишната температура на въздуха за периода 1931-1970 за ст. Банско е $9^{\circ} \mathrm{C}$, за ст. Гоце Делчев е $11,4^{\circ} \mathrm{C}$ и за връх Вихрен e $3,5^{\circ} \mathrm{C}$ (Kyuchukova, 1983). Почвената покривка включва предимно кафяви горски, излужени канелени горски и вторично затревени кафяви горски почви (фиг. 2), тъмнокафяви и тъмно оцветени горски и планински ливадни

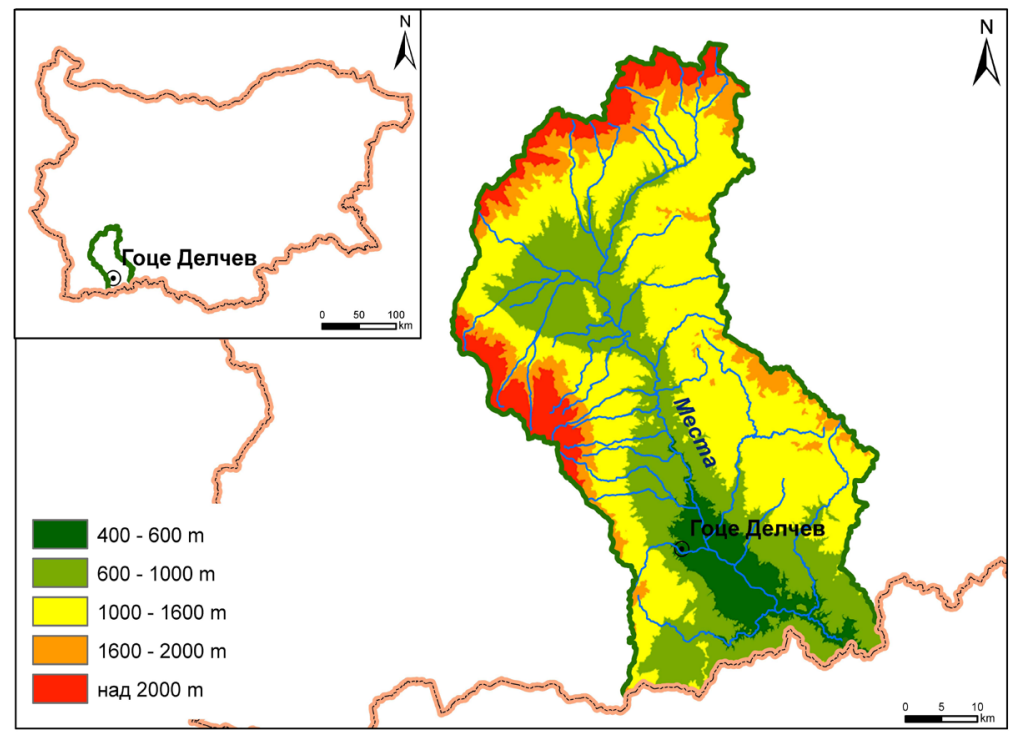

Фиг. 1. Местоположение и релеф (по данни от цифров модел на релефа $30 \mathrm{~m}$ ) на водосбора на р. Места Fig. 1. Location and topography (data from Digital Elevation Model $30 \mathrm{~m}$ ) of the catchment area of the Mesta River Basin

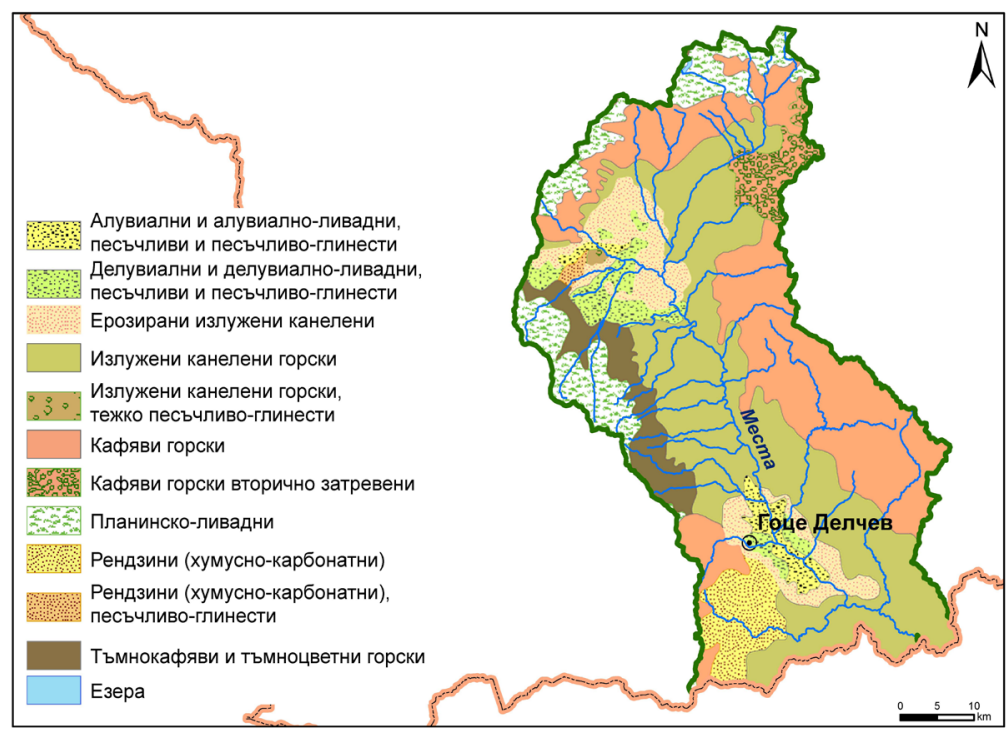

Фиг. 2. Почвена покривка в района на басейна на р. Места

Fig. 2. Soil cover in the Mesta River Basin 
почви, хумусно-карбонатни почви (рендзини) и алувиално-ливадни почви (върху алувия на речните тераси) (Ninov, 1997, 2002). Пространствените данни за почвите са получени по проект JICA (2006-2008) ${ }^{4}$.

Около половината от площта на водосбора на р. Места е заета от гори. Преобладават иглолистните, следвани от нискостеблените и най-малко са широколистните. Естествената растителност е преходно-средиземноморска и се отнася към Македоно-Тракийската растителна провинция (Bondev, 2002). Растителната покривка е разнообразна, представена е от благун, цер, келяв габър, космат дъб, виргилиев дъб (Bondev, 2002). Иглолистните са представени от бял и черен бор, смърч, ела, бяла и черна мура.

\section{Геоложка характеристика}

В геоложкия строеж на изследвания район участват скали с докамбрийска, палеозойска, кредна, палеогенска, плиоценска и кватернерна възраст (фиг. 3). Докамбрийските скали са метаморфозирани, представени от гнайси, шисти, амфиболити. Тези скали, заедно с палеозойският комплекс имат най-широко разпространение. Палеозоят е представен от южнобългарските гранитоиди, широко разпространени в антиклиналните структури. Долно и горнокредните материали са представени от интрузивни скали (гранити и гранитопорфири). Палеогенът е широко застьпен в грабеновите структури. Скалният комплекс на палеогена е разнообразен и се състои от седиментни, вулканогенноседиментни и вулкански скали. Плиоценът и Кватернерът запълват Разложката и Гоцеделчевската котловина.

\section{Хидрогеоложка характеристика}

За района на изследвания водосборен басейн, използвайки пространственото разпространение на геоложките разновидности по данни от геоложки картни листове в М 1:100 000: к.л. Велинград (Dimitrova, Katskov, 1990), к.л. Разлог (Marinova, Zagorchev, 1990), к.л. Белица (Marinova, Katskov, 1990), к.л. Доспат (Kozhoukharov et al., 1990) и к.л. Гоце Делчев (Kozhoukharov, Marinova, 1991) e съставена хидрогеоложка карта (фиг. 4), показваща пространственото разпространение на типовете колектори с формирани в тях подземни води. Съгласно последната хидрогеоложка карта на подземните води в България в M 1:500 000 (Pentchev et al., 2004), в басейна на р. Места се отделят следните хидрогеоложки формации: главен водонос: геоложка формация с висока пропускливост (А); главен водонос: геоложка формация със средна пропускливост (Б); второстепенен водонос: геоложка формация с ниска пропускливост (С) и водонос с незначителни водни ресурси (D) - (фиг. 5).

В изследвания водосборен басейн са формирани порови, пукнатинни и карстови води. Поровите води са акумулирани в плиоценските и кватернерните отложения, разпространени в най-младите грабенови структури (Разложката котловина и Гоцеделчевската котловина). Те се явяват самостоятелни басейни на ненапорни и напорни подземни води с активна циркулация (пресни подземни води). Пукнатинната система е привързана към палеогенските седименти, вулканогенно-седиментните и вулканските скали, гранитоидите и метаморфитите на палеозоя и докамбрия. Пукнатинните води формират водоносната система в зоната на регионалната напуканост в планинската и нископланинската зона на планините Пирин и Рила и западната част на Западни Родопи.

\footnotetext{
${ }^{4}$ Japan International Cooperation Agency (JICA) (2006-2008). Project: The Study on Integrated Water Management in the Republic of Bulgaria, GIS Database.
} 


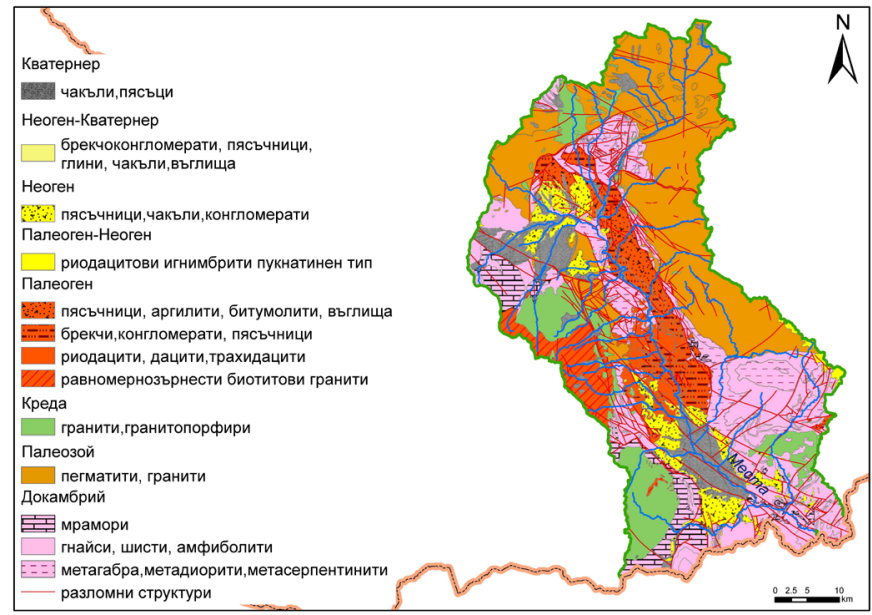

Фиг. 3. Геоложка карта за басейна на р. Места (по данни от геоложки картни листове M1:100 000 Велинград, Разлог, Белица, Доспат, Гоце Делчев)

Fig. 3. Geological map for the Mesta River Basin (data from geological map sheets in scale 1:100,000 - Velingrad, Razlog, Belitsa, Dospat, Gotse Delchev)
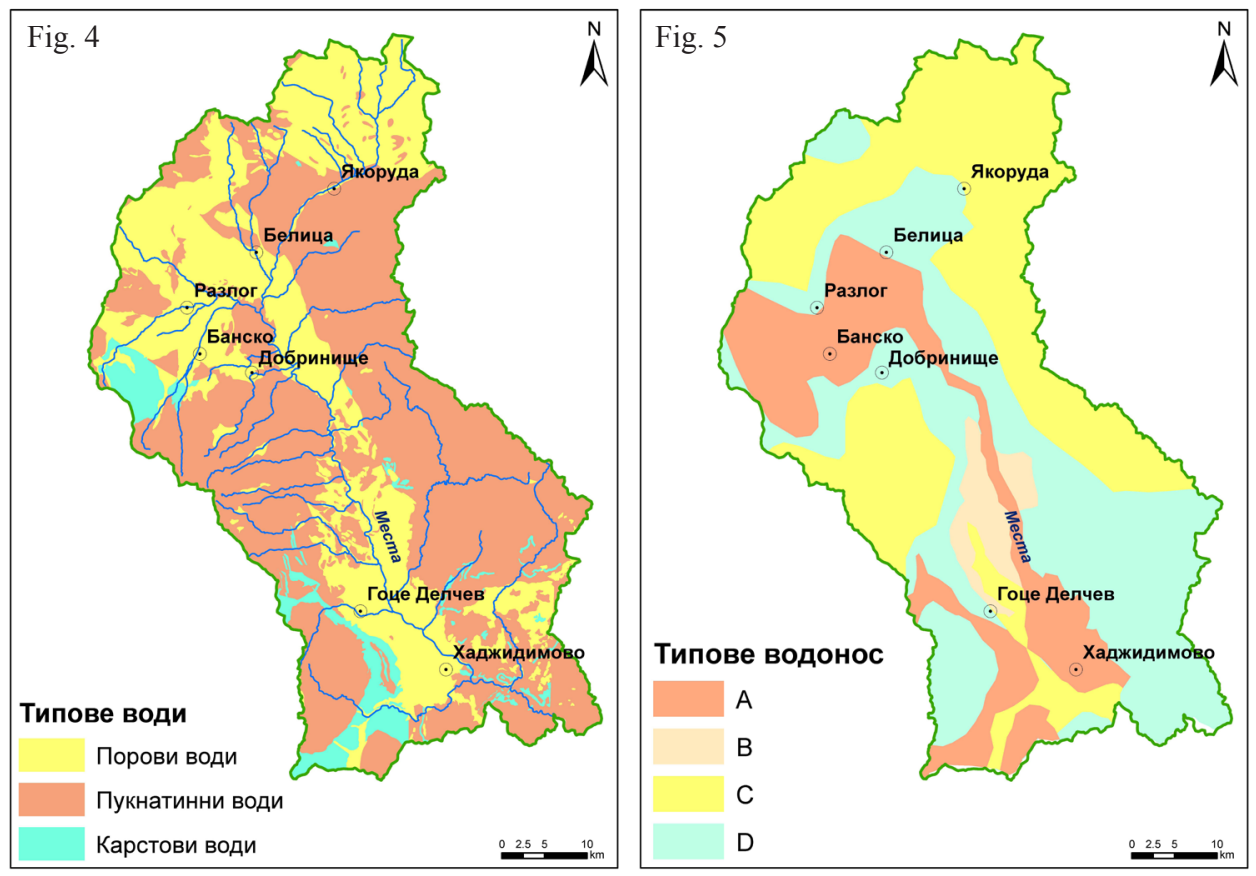

Фиг. 4. Типове подземни води в басейна на р. Места Fig. 4. Types of groundwater in the Mesta River Basin

Фиг. 5. Хидрогеоложки формации в басейна на р. Места по Пенчев и др. (Penchev et al., 2004) (A - главен водонос: геоложка формация с висока пропускливост; В - главен водонос: геоложка формация със средна пропускливост; C - второстепенен водонос: геоложка формация с ниска пропускливост; D - водонос с незначителни водни ресурси)

Fig. 5. Hydrogeological formations in the Mesta River Basin by Penchev et al. (2004) (A - Major aquifer: Hydrogeological formation with high permeability and/or productivity; B - Major aquifer: Hydrogeological formation with middle permeability and/or productivity; $\mathrm{C}$ - Minor aquifer: Hydrogeological formation with low permeability and/or productivity; D - Hydrogeological formation with very low permeability and/or productivity) 
В хидрогеоложко отношение най-голямо значение има карбонатната свита на протерозойския комплекс, представена от мрамори, носители на значително количество карстови води, които образуват самостоятелни басейни и карбонатно-силикатната свита на протерозойския комплекс, представена от мраморни прослойки.

Най-голямо площно разпространение в изследвания район имат пукнатинните води. Те се използват чрез каптиране на извори за питейни цели от много населени места, включително от големите градове в поречието на р. Места - Гоце Делчев, Белица и Якоруда. Част от напуканите скали се разкриват на земната повърхност, вследствие на което водата има естествени проявления, а друга част се намира под плиоценските скали. Пукнатинните води са привързани към скали: с докамбрийска възраст (гнайси; гнайсошисти; калкошисти; мигматити; амфиболити; лептинити); с палеозойска възраст (гранити, гранодиорити); в скали с горнокредна възраст (гранити); от палеогенския седиментен комплекс (конгломерати, брекчоконгломерати, пясъчници); от вулканогенния палеогенски комплекс (риодацити, дацити, трахиандезити); от седиментогенновулканогенния палеогенски комплекс (конгломерати, брекчи, туфозни пясъчници, туфи, пясъчници, алевролити).

\section{Земно покритие и земеползване}

По данни от проект КОРИНЕ Земно покритие $2000^{5}$ в изследвания район се наблюдават 19 класа земно покритие и земеползване, класифицирани по номенклатурата на КОРИНЕ Земно покритие 2000. Те са представени от антропогенни обекти, земеделски земи, гори и полуестествени площи. В този мащаб водните обекти не са очертани, поради недостатъчна площ. Повече от половината от поречието на р. Места е заето от гори и полуестествени площи (около 76 \%), като най-голямо развитие имат иглолистните гори, простиращи се на площ от около $930 \mathrm{~km}^{2}$ или $33 \%$ от площта на басейна, следвани от смесените и широколистните масиви. Земеделските земи със значителни участъци естествена растителност са около $13 \%$ от водосбора на Места.

\section{Химически състав на подземните води}

Анализът за химичния състав на подземните води от зоната с активен водообмен (хипергенната зона) е извършен въз основа на данни от карти за състава на подземните води за територията на България в М 1:1 000000 (Кехайов, 1982ф). Картите са дигитализирани в средата на ГИС, след което са изрязани по контура на изследвания басейн. Получените карти показват пространственото разпределение на главните компоненти, определящи геохимичния облик на подземните води (хидрогенкарбонати, сулфати, хлориди, калций, магнезий, натрий) и интегрираните показатели като минерализация и обща твърдост.

Подземните води в изследваното поречието са пресни. Минерализацията им за по-голямата част от водосбора е под $0,2 \mathrm{~g} / \mathrm{l}$. В южната част от басейна тя е в границите от 0,2 до 0,5 g/1 (фиг. 6).

По класификацията на Алекин (Alekin, 1953) на територията на басейна се отделят две хидрохимични зони (фиг. 7) или два типа подземни води, съгласно съотношението между аниони и катиони или: $\mathrm{HCO}_{3}^{-}>\mathrm{Ca}^{2+}+\mathrm{Mg}^{2+}$ (води от първи тип) и $\mathrm{HCO}_{3}^{-}<\mathrm{Ca}^{2+}+\mathrm{Mg}^{2+}<\mathrm{HCO}_{3}{ }^{-}+\mathrm{SO}_{4}{ }^{2-}$ (води от втори тип). Най-широко разпространение имат водите от първи тип, разпространени във високопланинската, планинската и нископланинската зона, където широко развитие имат силикатните скали. Тези води са привързани към

${ }^{5}$ Корине земно покритие 2000 - България, дигитална база данни. 
зоната на регионалната напуканост на докамбрийския метаморфен комплекс, представен от гнайси, гранитогнайси, амфиболити и към пукнатинната среда на южнобългарските гранити и гранитоиди, кварцитите, конгломератите и мергелите на палеозоя. Формирането им е в резултат на хидролиза и инконгруентно разтваряне (излужване) на силикатните скали, съдържащи голямо количество натрий и калций. Голямата интензивност на водообмена в съчетание с химическата инертност на пукнатинната среда, плитката почвена покривка, представена основно от кафяви горски, кафяви горски вторично затревени и планинско-ливадни почви, обезпечават по-ниската минерализация на водите.
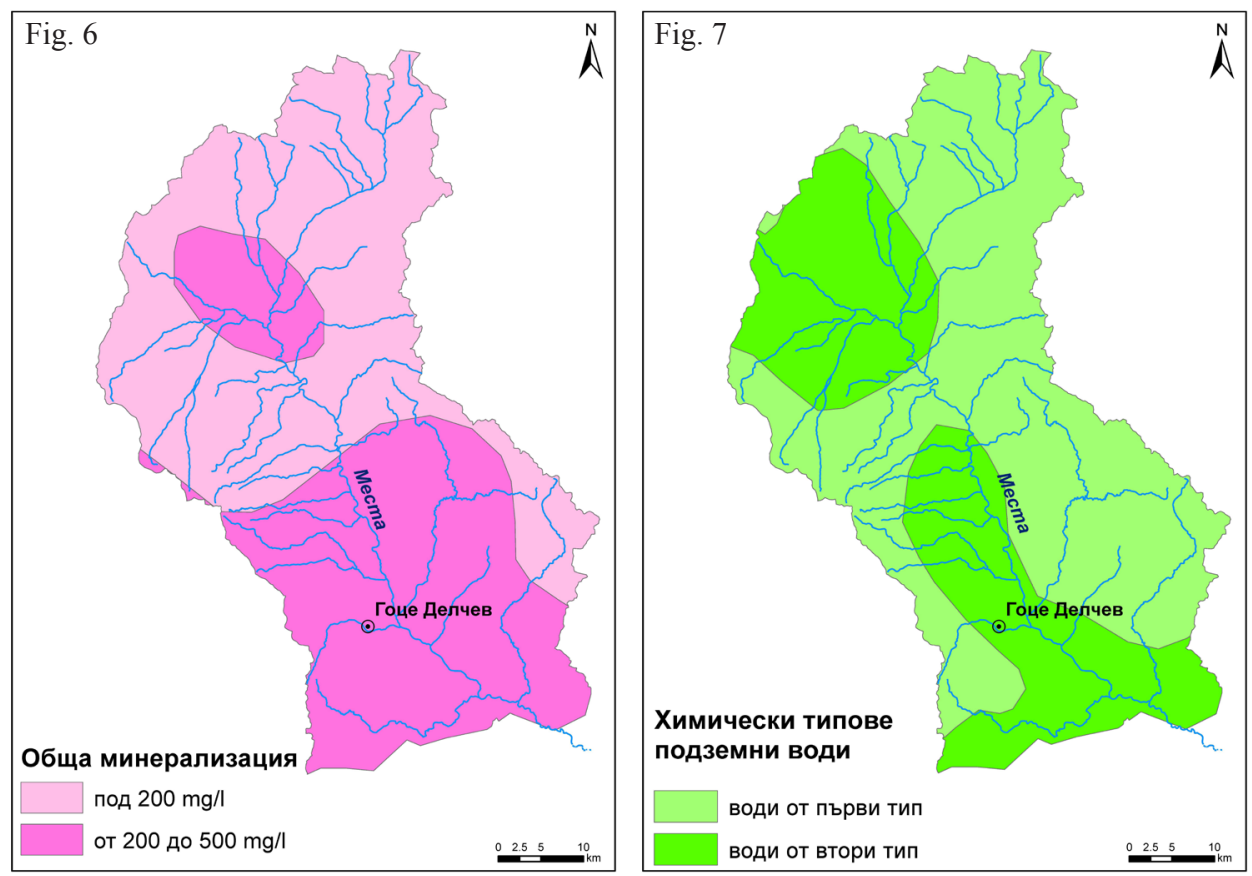

Фиг. 6. Минерализация на подземните води по Кехайов (1982ф)

Fig. 6. Groundwater mineralization by Kehajov (Кехайов, 1988ф)

Фиг. 7. Химически типове подземни води по Кехайов (1982ф)

Fig. 7. Chemical types of groundwater by Kehajov (Кехайов, 1982ф)

Водите от втория тип са привързани към котловинните райони, с минимални валежи, където са акумулирани порови води в плиоценските и кватернерните седименти. Почвената покривка е представена основно от излужени канелени горски почви, образувани в условията на влияние на широколистни гори. Формирането на водите е в резултат на разтварянето на изветрителните продукти и почвеното засоляване.

По твърдост (класификация на Алекин) подземните води от басейна на р. Места са от много меки до меки (твърдост под 3 meq/l) и умерено твърди (от 3 до $6 \mathrm{meq} / \mathrm{l})$ в южната част на водосбора (фиг. 8).

Съгласно уравнението на Курлов, илюстриращо веществения състав на водите, подземните води от поречието на р. Места са хидрокарбонатно-калциевомагнезиеви и хидрокарбонатно-калциево-магнезиево-натриеви. 


\section{Качествена оценка на подземните води}

Картите за в пространственото разпределение на химичните компоненти във водосборния басейн на р. Места са векторизирани по картите на Кехайов (1982ф) за територията на България. Количествените стойности на отделните компоненти са сравнени със стандарта по Приложение № 1 към чл. 10, ал.2, т. 1 на Наредба № 1/10.10.2007 .

От направения анализ се установи, че в регионален мащаб подземните води от водосборния басейн на р. Места не са с концентрации над пределно допустимите норми по Наредба № 1 по основните физико-химични показатели (обща твърдост, нитрати, сулфати, хлориди), метали и металоиди (мед, никел, олово, хром, алуминий, желязо, манган, цинк, арсен, калций, магнезий, натрий).

Хлоридите са в норма по Наредба 1 и за по-голямата част от водосбора те са под 10 mg/l (фиг. 9), което е показател за липса на антропогенно замърсяване. Нитратите са под $10 \mathrm{mg} / \mathrm{l}$ за северната част от водосбора и от 10 до $30 \mathrm{mg} / \mathrm{l}$ за южната (фиг. 10). Нитратите са показател за наличие на старо замърсяване, тъй като веднъж преминали в зоната на аерация и в наситената зона, трудно се елиминират от течната фаза. При антропогенно замърсяване вследствие на наторяване се получава натрупване на нитратния йон в подземните води. Сулфатният йон е широко разпространен в подземните води, което е вследствие на голямото многообразие на форми и пътища на миграция на сярата, влизаща в
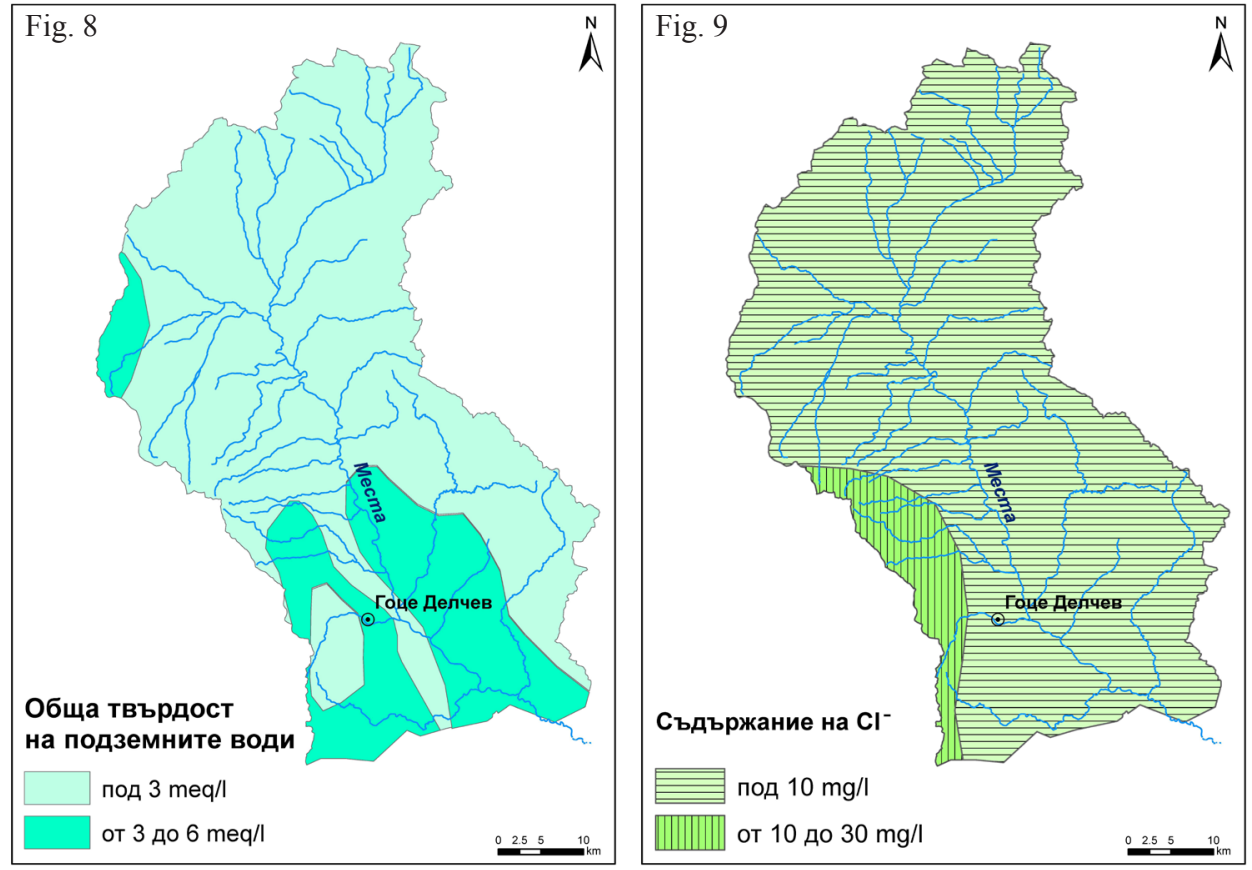

Фиг. 8. Обща твърдост на подземните води по Кехайов (1982ф)

Fig. 8. Total groundwater hardness by Kehajov (Кехайов, 1982ф)

Фиг. 9. Концентрация на хлориди по Кехайов (1982ф)

Fig. 9. Concentration of chlorides by Kehajov (Кехайов, 1982ф)

${ }^{6}$ Наредба № 1 / 10.10.2007 за проучване, ползване и опазване на подземните води. 
състава на много минерали. Концентрацията на сулфатите (фиг. 11) е доста под допустимото съдържание от $250 \mathrm{mg} / \mathrm{l}$. По отношение на натрия, подземните води от басейна на р. Места са със съдържание до $30 \mathrm{mg} / 1$ (фиг. 12) в южната част и под $10 \mathrm{mg} / 1$ за северната част, което също е доста под допустимата концентрация по Наредба 1.

Концентрацията на желязото се движи в границите под 0,02 до 0,02-0,05 и 0,05-0,1 mg/l (фиг. 13). Концентрацията на хром е доста под пределно допустимата концентрация по Наредба 1 от $0,01 \mathrm{mg} / 1$, както и концентрацията на никел, която също е доста под допустимата концентрация от $0,02 \mathrm{mg} / \mathrm{l}$. По показател олово, ситуацията е различна. За по-голямата част от изследвания район концентрацията е под пределно допустимата от $0,01 \mathrm{mg} / \mathrm{l}$, а за останалата част тя е на границата на допустимата концентрация от $0,01 \mathrm{mg} / \mathrm{l}$ (фиг. 14). По отношение на елемента мед (фиг. 15) е трудно да се прецени каква е ситуацията, тъй като за ЮИ част от изследвания район стойността е над $0,02 \mathrm{mg} / \mathrm{l}$, което е под допустимата стойност по Наредба 1 от 2 mg/l, но не е ясно каква е максималната стойност по така дадените резултати. Съдържанието на цинк, алуминий и манган е под допустимата концентрация по Наредба 1.

Актуалното състояние на подземните води от изследвания водосборен басейн е дадено в интернет сайта на Геоинформационна система за управление на водите и докладване. По данни от ИАОСВ и качената информация в Геоинформационна система за управление на водите и докладване по Програма BG02 „Интегрирано
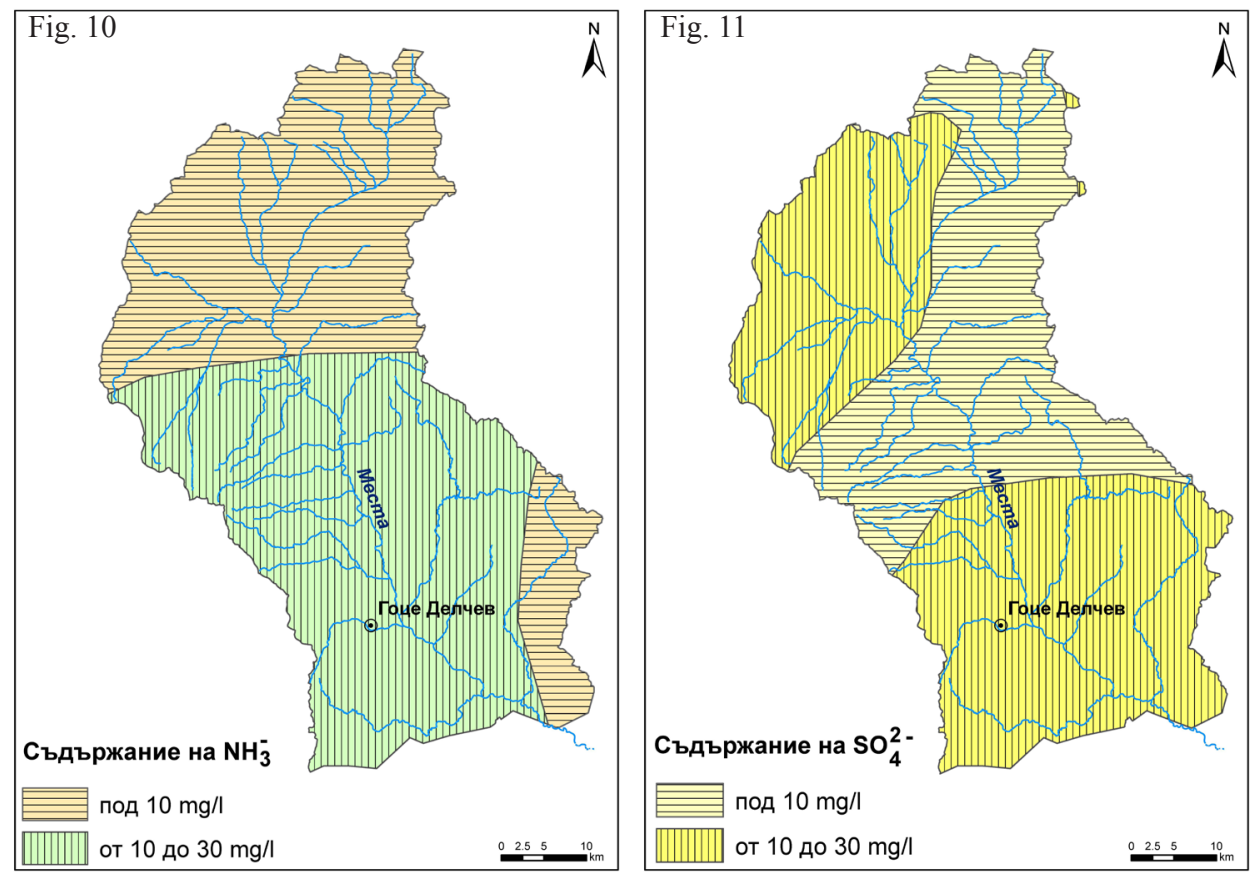

Фиг. 10. Концентрация на нитрати по Кехайов (1982ф)

Fig. 10. Concentration of nitrates by Kehajov (Кехайов, 1988ф)

Фиг. 11. Концентрация на сулфати по Кехайов (1982ф)

Fig. 11. Concentration of sulfates by Kehajov (Кехайов, 1982ф) 

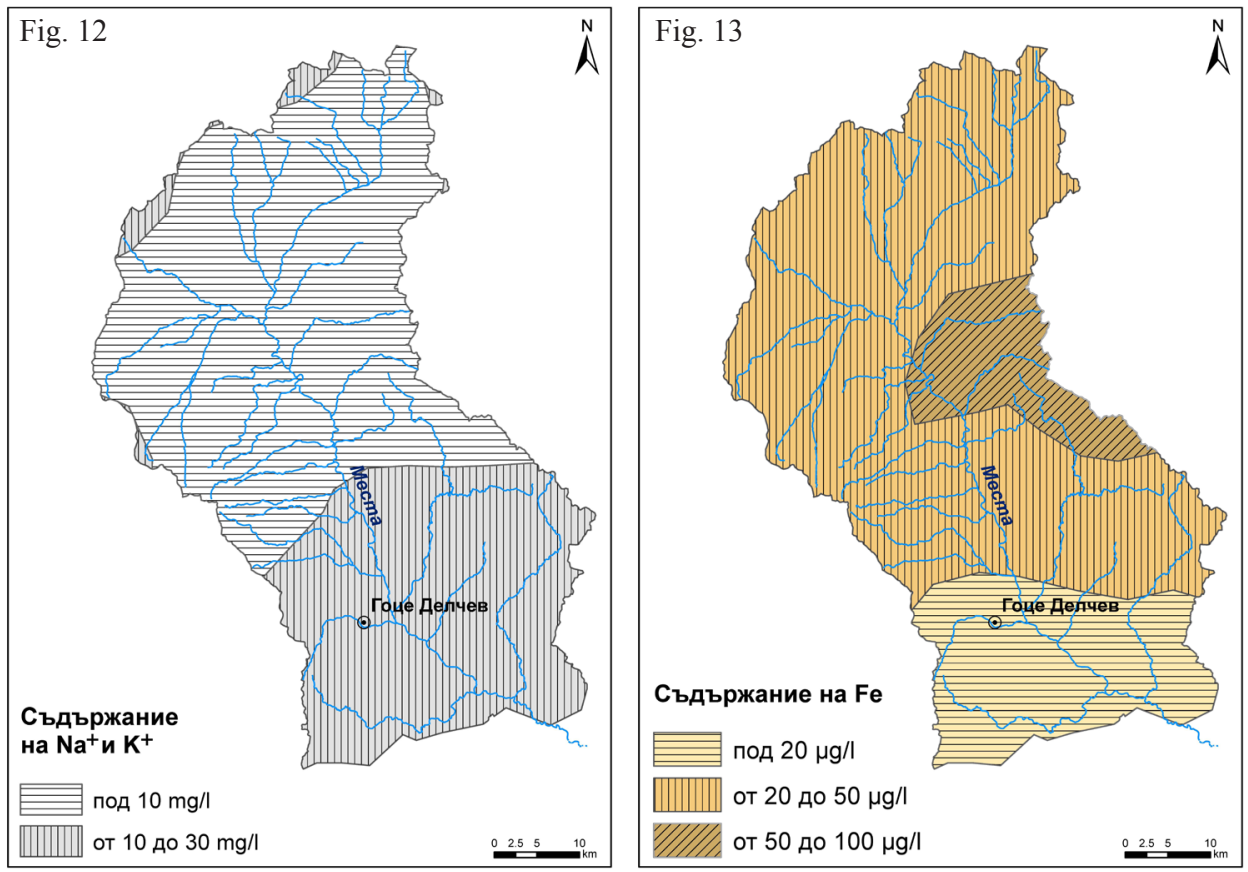

Фиг. 12. Концентрация на натрий и калий по Кехайов (1982ф)

Fig. 12. Concentration of sodium and potassium by Kehajov (Кехайов, 1982ф)

Фиг. 13. Концентрация на желязо по Кехайов (1982ф)

Fig. 13. Concentration of iron by Kehajov (Кехайов, 1982ф)
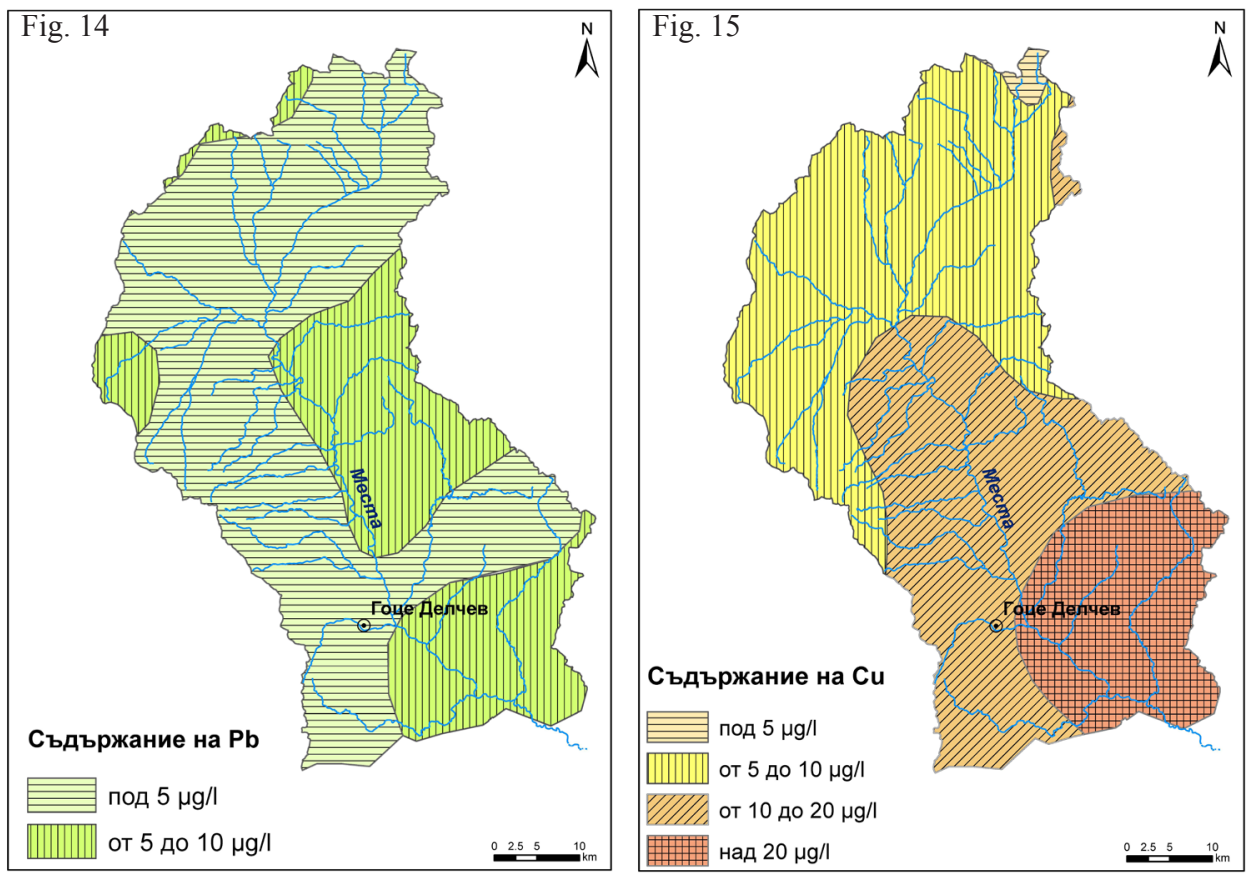
Фиг. 14. Концентрация на олово по Кехайов (1982ф)

Fig. 14. Concentration of lead by Kehajov (Кехайов, 1982ф)

Фиг. 15. Концентрация на мед по Кехайов (1982ф)

Fig. 15. Concentration of copper by Kehajov (Кехайов, 1982ф)

управление на морските и вътрешните води“, Проект „Надграждане на геоинформационната система за управление на водите и докладване” (2017), Финансов механизъм на Европейското икономическо пространство 2009-2014, попадащите в изследвания водосбор подземни водни тела са в добро състояние или не са в риск от замърсяване.

\section{Заключение}

Подземните води - порови, пукнатини и карстови, от водосборния басейн на p. Места са хидрокарбонатно-калциево-магнезиеви с повишено съдържание на натрий. Съдържанието на анионите в подземните води е в последователността: $\mathrm{HCO}_{3}^{-}>\mathrm{SO}_{4}{ }^{2-}>\mathrm{Cl}^{-}$. Катионите са подредени в реда: $\mathrm{Ca}^{2+}>\mathrm{Mg}^{2+}>\left(\mathrm{Na}^{+}+\mathrm{K}^{+}\right)$или $\mathrm{Ca}^{2+}>\left(\mathrm{Na}^{+}+\mathrm{K}^{+}\right)>\mathrm{Mg}^{2+}$. Най-широко разпространение имат водите от първи тип или $\mathrm{HCO}_{3}^{-}>\mathrm{Ca}^{2+}+\mathrm{Mg}^{2+}$. Те са привързани към местата на развитие на силикатните скали, разпространени във високопланинската, среднопланинската и нископланинската зона. Водите от втория тип $\left(\mathrm{HCO}_{3}{ }^{-}<\mathrm{Ca}^{2+}+\mathrm{Mg}^{2+}<\mathrm{HCO}_{3}\right.$ $\left.+\mathrm{SO}_{4}{ }^{2-}\right)$ са привързани към котловинните райони, с минимални валежи, покрити от плиоценски и кватернерни седименти. Подземните води са от много меки до умерено твърди, пресни, с минерализация до $0,5 \mathrm{~g} / 1$ и съдържание на хлор под 10 $\mathrm{mg} / \mathrm{l}$. Съдържанието на нитрати е до $30 \mathrm{mg} / \mathrm{l}$, което е показател за липса на старо атропогенно замърсяване от неконтролируемо наторяване с азотни торове.

\section{Благодарности}

Настоящото изследване е проведено във връзка с изпълнението на Национална научна програма (ННП) „Опазване на околната среда и намаляване на риска от неблагоприятни явления и природни бедствия“", одобрена с Решение на МС № 577/17.08.2018 г. и финансирана от МОН (Споразумение № Д01-230/06.12.2018 г.).

\section{Литература}

\section{References}

Alekin, O. A. 1953. Basics of hydrochemistry. Hydrometeorological Publishing House, Leningrad, 296 p. (in Russian).

Antonov, H., D. Danchev. 1980. Groundwater in the Republic of Bulgaria. Sofia, 360 p. (in Bulgarian).

Bondev, Iv. 2002. Section 5. Vegetation. Point 5.4. In: Geography of Bulgaria. 2002. ForKom Publishing House, Sofia, 336-351. (in Bulgarian).

Cheshitev, G., I. Kanchev (eds). 1989. Compiled by Cheshitev, G., I. Kanchev, V. Valkov, R. Marinova, Y. Shilyafova, M. Russeva, K. Iliev. Geological map of Bulgaria in scale 1:500 000. Committee of Geology of Bulgaria.

Dimitrova, R., N. Katsakov. 1990. Geological Map of Bulgaria on Scale 1:100 000. Velingrad Map Sheet. Committee of Geology, Enterprise of Geophysical Survey and Geological Mapping.

Kozhoukharov, D., R. Dimitrova, N. Katsakov. 1990. Geological Map of Bulgaria on Scale 1:100 000. Dospat Map Sheet. Committee of Geology, Enterprise of 
Geophysical Survey and Geological Mapping.

Kozhoukharov, D., R. Marinova. 1991. Geological Map of Bulgaria on Scale 1:100 000. Gotce Delchev Map Sheet. Committee of Geology, Enterprise of Geophysical Survey and Geological Mapping.

Koleva, E., R. Peneva. 1990. Climate Guide. Precipitation in Bulgaria. Bulgarian Academy of Sciences, Sofia, 169 p. (in Bulgarian).

Kyuchukova, M. 1983. Climate Guide of the Republic of Bulgaria. Volume 3. Temperature of the Air, Temperature of the Soil, Frost. Bulgarian Academy of Sciences, Sofia, 440 p. (in Bulgarian).

Marinova, R., Iv. Zagorchev. 1990. Geological Map of Bulgaria on Scale 1:100 000, Razlog Map Sheet. Committee of Geology, Enterprise of Geophysical Survey and Geological Mapping. (in Bulgarian).

Marinova, R., N. Katsakov. 1990. Geological Map of Bulgaria on Scale 1:100 000 Belitsa Map Sheet. Committee of Geology, Enterprise of Geophysical Survey and Geological Mapping.

Ninov, N. 1997. Soils. In: Geography of Bulgaria. "Prof. Marin Drinov" Publishing House, Sofia, 225-259 (in Bulgarian).

Ninov, N. 2002. Section 4. Soils. In: Kopralev, I., Yordanova, M., Mladenov, Ch. (eds). Geography of Bulgaria. ForKom Publishing House, Sofia, 277-316 (in Bulgarian).

Pentchev, P. P., C. P. Gyurov, N. T. Stoyanov, V.P. Petrov. 2004. A Digital Groundwater Map of Bulgaria in 1:500 000 Scale - Objectives and Methodological Approach. In: Proceedings of the Conference on Water Observation and Information Systems for Decision Support BALWOIS 2004, Ohrid, FY Republic of Macedonia, 25-29 May, Publisher: Ministry of Education and Sciences of Republic of Macedonia, $1-9$.

Sabev, L., St. Stanev. 1963. Climatic regions of Bulgaria and their climate. Zemizdat. Sofia, 181 p. (in Bulgarian).

Постьпила: 21.10 .2019

Приета: 11.11.2019
Received: 21 October 2019 Accepted: 11 November 2019 